University of Nebraska - Lincoln

DigitalCommons@University of Nebraska - Lincoln

Dissertations, Theses, \& Student Research,

Department of History

History, Department of

Spring 2009

\title{
The Sand Creek Phenomenon: The Complexity and Difficulty of Undertaking a Comparative Study of Genocide vis-à-vis the Northern American West
}

Brenden Rensink

Follow this and additional works at: https://digitalcommons.unl.edu/historydiss

Part of the History Commons

Rensink, Brenden, "The Sand Creek Phenomenon: The Complexity and Difficulty of Undertaking a Comparative Study of Genocide vis-à-vis the Northern American West" (2009). Dissertations, Theses, \& Student Research, Department of History. 26.

https://digitalcommons.unl.edu/historydiss/26

This Article is brought to you for free and open access by the History, Department of at DigitalCommons@University of Nebraska - Lincoln. It has been accepted for inclusion in Dissertations, Theses, \& Student Research, Department of History by an authorized administrator of DigitalCommons@University of Nebraska - Lincoln. 


\title{
The Sand Creek Phenomenon:
}

\section{The Complexity and Difficulty of Undertaking a Comparative Study of Genocide vis-à-vis the Northern American West}

\author{
Brenden Rensink \\ Department of History, University of Nebraska-Lincoln
}

\begin{abstract}
This article explores various issues germane to the field of the history of the North American West and the struggle to integrate these issues into the broader field of genocide studies. The primary historiographic example of the 1864 Sand Creek Massacre of Cheyennes and Araphahos in southeastern Colorado by the Colorado Militia illustrates the difficulties of producing objective research on such morally charged historical events. Specific attention is dedicated to understanding the potential value of integrating Native American history into the broader field of genocide studies and to explaining why comparative scholarship has yet to be undertaken in any substantial way. Building on this foundation, the article reveals the challenges facing genocide scholars in integrating the history of the North American West into the field of genocide studies, particularly in a comparative sense.
\end{abstract}

Keywords: Native American, American Indian, Sand Creek Massacre, genocide, American West

\section{Introduction}

On the morning of 29 November 1864, the Colorado Third Cavalry launched an attack on Chief Black Kettle's Cheyenne and Arapaho encampment at Sand Creek, with dramatic and horrific results. Commonly known as the Sand Creek Massacre, the ensuing conflict resulted in the death of hundreds of Native Americans and, most strikingly, the killing and mutilation of many women, children, and elderly individuals. The gruesome scene launched an immediate firestorm of public, congressional, military, and historical debate that has continued unresolved to the present day. As is to be expected, the apparent injustice of the event was not lost on contemporaries or on subsequent historians. However, the complex events that led up to and help explain the massacre have often been marginalized by authors trying either to condemn Colonel John M. Chivington, the Colorado Third Cavalry, and Governor John Evans for their actions or to absolve them of any guilt. Herein lies the foundational crisis in integrating Native American history into the field of comparative genocide studies.

John M. Chivington, colonel and leader of the Colorado Third Cavalry, the primary military unit at the Sand Creek Massacre, was originally a Methodist minister. Arriving in Denver from Omaha in 1860, Chivington was appointed presiding elder of the Rocky Mountain District of the Methodist Church. ${ }^{1}$ With the outbreak of the Civil War soon 
thereafter, Chivington offered his services as a regimental chaplain for the Colorado volunteers, but was instead appointed major of the regiment. ${ }^{2}$ He served in this capacity, combating Confederate threats in the area, until 1862, at which time he was appointed commander of the Military District of Colorado. In August 1864, a new volunteer unit, the Colorado Third Cavalry, was raised, with Colonel Chivington as its leader. The Third Cavalry's term of service was to last 100 days, and the unit was given the express mission of quelling any Indian hostilities in the region. ${ }^{3}$ The unit more closely resembled a local militia than a US Cavalry regiment, and it was largely untrained in military maneuvers and discipline. By late November, the unit's term of service was nearly up, and it had not yet engaged in battle. As a result they earned the moniker "The Bloodless Third," and thus they were eager to see action when they arrived at Fort Lyon, near Sand Creek, where Black Kettle's band had originally come to make peace.

Overseeing all of these activities was John Evans, who had served as Colorado's territorial governor since the fall of 1862. Originally trained in medicine, Evans had become involved in politics while supporting Lincoln's 1860 campaign and was offered first the governorship of Washington, which he turned down, and then the same position in Colorado. ${ }^{4}$ Seeking to resolve the escalating conflict with the Plains tribes, Evans issued a series of proclamations authorizing the destruction of all "hostile Indians." 5 The objective of these proclamations was to separate the Natives into two discernible groups, which would be dealt with accordingly. It was in this context that Chivington's Third Cavalry was organized and charged with the duty of dealing with those Indians still at war. Because he had to report regularly to the commissioner of Indian affairs and to the US War Department, Evans had political motivations to end the hostilities in his territory quickly.

Under these circumstances, in the late fall of 1864, a camp of Cheyennes, led by Chief Black Kettle, approached Major Edward Wynkoop at Fort Lyon and sued for peace. Wynkoop was not a career military man, but had risen in rank during the Confederate struggles with neighboring Texas. When Chivington was promoted to colonel, Wynkoop was promoted to major, placed in command of Fort Lyon, and assigned control over Union troops stationed to protect against an attack from the south. ${ }^{6}$ When approached by Chief Black Kettle, Wynkoop instructed him to have his people camp temporarily on nearby Sand Creek, where, Wynkoop promised, they would be protected and provided with provisions. ${ }^{7}$ Subsequently, Wynkoop took Cheyenne Chief Black Kettle and Arapaho Chief White Antelope to Denver to present their case to Governor Evans. As will be discussed later, Evans was less than eager to accept peaceful terms from these chiefs, who were well known to have allowed some of the younger members of their tribes to engage in violence in the recent past. Ultimately, both chiefs were sent back to Sand Creek. Soon afterwards Wynkoop was replaced by Major Scott Anthony, who displayed a less conciliatory attitude toward the Natives. When Chivington and his Third Cavalry arrived unannounced at Fort Lyon on 27 November 1864, they quickly began preparing to attack the encampment at Sand Creek. On the morning of 29 November, Chivington's troops attacked Black Kettle's sleeping encampment. The attack lasted for most of the morning and early afternoon.

Investigations into the event revealed an array of conflicting facts that should be of interest to scholars interested in comparative genocide studies. Was Chivington's proclaimed policy to "kill all and scalp all, little and big" an example of genocidal policy, or is it to be understood in the broader military context of an ongoing struggle between the United States and Plains Indians? ${ }^{8}$ While the term "genocide" was not part of Chivington's lexicon, some twentieth-century scholars (including Ward Churchill, Annette Jaimes, and David 
Stannard) have applied this term to his actions and those of the Colorado Third Cavalry. ${ }^{9}$

Such tragic events and violent rhetoric should prove fertile soil for comparative genocide research. Unfortunately, this has not been the case. Instead, contemporary reports and accounts, as well as scholarly commentary and historiography, represent a disarray of diametrically opposed interpretations of the historical facts of this conflict, not to mention its causes and consequences. Eyewitnesses and subsequent scholars describe identical events and interpret identical documents with striking disparity. The controversy exemplified by the Sand Creek Massacre encumbers objective scholarship and plagues much of North American West history.

The tragedy so vividly manifest in the Sand Creek Massacre is an inescapable undertone of North American history. The word "inescapable" is appropriate here because it is truly impossible to ignore or disregard the inherent sorrow and loss that accompany so many historical events in the continent's past. For every step forward of Euro-American development and triumph, there was a mirrored reaction of regress and loss for the indigenous inhabitants of North America. America's history of geographic expansion and cultural achievement must be tempered by the constant reminder of the unseen or even ignored costs it exacted from Native Americans. This dichotomy is inescapable. Euro-American contact led to the decimation of indigenous populations, a disastrous alteration of their culture, and a permanent change to their physical world. ${ }^{10}$ Those who escaped death and disease suffered the imposition of a foreign culture, will, and identity. To speak in such terms can be dangerous, as it may appear to relegate Native populations to the status of mere objects to be acted upon - to constrict them in a straitjacket of victimization, offering them no voice and denying them agency within their own history. Indeed, historian Patricia Limerick has warned against histories that portray "Indians as victims, passive people who stood frozen in place as a great wave of white expansion crashed down on them and left them broken and shattered." 11 Even with this consideration in mind, however, one cannot escape the overarching misfortune that befell Native Americans.

There are various worthy reasons for studying Native American history and attempting to resolve, or at least to contextualize, its many controversies. Rectifying inaccuracies in past accounts, building awareness of one's ancestors, and simply increasing and disseminating knowledge are important goals. Yet another goal is to contribute to the field of genocide studies, and particularly the comparative study of genocide. Throughout world history there are examples of atrocities, massacres, and genocides that merit careful study. As Israel Charny notes, this field of study seeks to

demonstrate that man's genocidal destructiveness can be seen as a process to be studied, charted, and managed correctively. ... If ever we are to curtail holocausts of human life, we must understand the cancers we are fighting. ${ }^{12}$

The history of the North American West clearly includes many examples of the destructive tendencies of human nature that typify the cancers of which Charny speaks.

If one accepts the reality that contact between Europeans/Euro-Americans and Native Americans led to the continental demographic collapse of North America's autochthonous populations, it is readily apparent how the place of Native American history in comparative genocide studies is significant; but it is equally significant that it has not played a more prominent role in such comparative scholarship. The demographic collapse of an entire continent's population surely involves events and trends that can be profitably compared with other aspects of world history; however, this has not been done. If prop- 
erly approached, with careful and objective methodology, North American history may reveal a wealth of valuable comparative topics for global application. Comparative genocide research in North America is a promising field awaiting proper development.

An examination of the Sand Creek historiography illustrates the problems that hinder such comparative research and enables the subsequent explanation of such problems. It is hoped that such analysis will point to ways of correcting negative trends and will help move forward the eventual integration of the history of the North American West and genocide studies.

\section{Sand Creek Historiography and the Struggle for Objectivity}

Because the 1864 Sand Creek Massacre is a prime candidate for comparative genocide research, the need for objective scholarship into what does and does not constitute genocide in the history of the North American West is especially pressing. One difficulty in examining those events that might be considered genocide is the biased nature of the primary documents themselves. The majority of the sources available to historians document a series of congressional hearings and investigations on the matter that took place between 1865 and 1867. The reports of these hearings contain the testimonies of all the military leaders involved in the massacre, as well as numerous eyewitness accounts from others present-military, civilian, and Indian. Given the severity of the accusations and the investigation at hand, the testimonies all reflect individuals' vested interests in either condemning or justifying the event. Some eyewitnesses and soldiers strove to clear their own names by condemning what occurred or by pinning guilt on others, while others described a series of events that largely excused their own, and their colleagues', wrongdoings - if any were admitted at all. ${ }^{13}$ Statements about the massacre made after the fact by Governor Evans and Colonel Chivington also reflect attempts to justify the attack on Black Kettle's encampment. Thus, the primary sources available are, by their nature, acutely biased. Not surprisingly, controversy and extreme interpretations of events have dominated the historiography of Sand Creek Massacre from the outset.

Immediately after the attack on Black Kettle's encampment by Chivington's Third Cavalry, public reactions polarized and the conflict became the subject of an official inquiry by the Department of War and Congress. The first words written on the subject were part of an open debate as to whether the events at Sand Creek constituted a battle or a massacre. ${ }^{14}$ Given the divisive foundations of the historiography, it comes as no surprise that this has been described as "one of our most controversial Indian conflicts." 15 The inherent bias of the sources, with their conflicting perspectives, has had direct consequences for the secondary literature analyzing the events. Coupled with the political legacies of Native American activist scholarship, the resulting historiography understandably proves problematic for comparative genocide research.

This does not imply that the events at Sand Creek and its historiography are representative of the whole of white-Indian interaction and the related fields of historical study. However, even in the uniqueness of the event and how it has been written about, those interested in the comparative study of genocide should find this case to be of interest. It is extremely difficult for historians to ascertain which of the many conflicting testimonies relating to this case are most valid. That said, regardless of the many inconsistencies in the testimonial accounts, certain facts can be established. First, the massacre did occur. Second, women, children, and the elderly were killed, and many bodies were mutilated. The uncertainty, self-serving prejudice, and biased opinions present in Sand Creek's primary 
documents, however, have provided ample ammunition for modern scholars to engage in debate over even such incontrovertible facts. Likewise, the documents have offered more than enough evidence to support both those who vilify Chivington and emphasize the innocence of the Indian victims and, conversely, those who wish to exonerate Chivington and "prove" that his actions were warranted. These motives and biases, present in the primary documents, are now manifest in the historical analysis as well.

Addressing a wide range of factual questions, historians of the Sand Creek Massacre have used various primary sources to arrive at very different conclusions. A thematic presentation of the primary debates at hand can be framed upon a set of introductory questions posed in William R. Dunn, Jr.'s I Stand By Sand Creek:

- Were the Cheyenne and Arapaho Indians camped at Sand Creek hostiles or friendlies?

- Were these Indians under protection of the United States Government?

- Was the fight at Sand Creek a massacre or a battle?

- Were excessively large numbers of women and children killed at Sand Creek?

- Did Colonel Chivington permit the scalping and mutilation of the Indian dead $?^{16}$

While Dunn's own answers to these questions are a prime example of unbalanced and biased research, his questions do provide a useful road map for a subsequent discussion of the matter. The opinions of those who defend Chivington will be examined first, followed by the opinions of those who condemn him. This thematic comparison will lay bare not only the conflicting historical analyses but the conflicting primary sources upon which they rely. The historiography of the Sand Creek Massacre thus illustrates how historians selectively using conflicting portions of the documentary evidence can come to diametrically opposed conclusions.

\section{Were Cheyennes and Arapahos camped at Sand Creek at peace or at war?}

According to William R. Dunn, Reginald Craig, and J.P. Dunn, the tribes encamped at Sand Creek had long been in a state of violent war with the region's settlers. ${ }^{17}$ All three authors assert that Indian attacks against settlers had taken place in the spring and summer of 1864 and that Black Kettle's supposedly admitted such attacks. Opposing this depiction, though not denying Cheyenne involvement in the violence on the Plains, others have sought to at least qualify Native actions. In her history of the Cheyenne, Mari Sandoz explains that they "had tried to keep peaceful" but were repeatedly driven by starvation to join with Comanche, Kiowa, and Sioux in their campaigns. ${ }^{18}$ Others have stressed that the Cheyenne involvement was limited to a small number of young warriors who were outside Black Kettle's control; the Indians camped at Sand Creek thus represented a peaceful band and should not be linked with Indian actions during the previous months and years. ${ }^{19}$

The motives behind the violent activities of both Native Americans and Chivington's Third Cavalry are another important issue that relates to the status of Black Kettle's band at Sand Creek. By painting a detailed picture of the Indians' misdeeds on the Plains, Craig presents the attack on Black Kettle's camp as a necessary, though regrettable, action (basically, a case of retaliation), meant to "teach them" a lesson and move them toward desiring peaceful relations. ${ }^{20}$ Craig reinforces this justification by insisting that Chivington 
was "appalled at the outbreak of full scale war," whereas the "Indians enjoyed savage torture and killing ... entirely without provocation." ${ }^{21}$ His juxtaposition of such portrayals makes clear his underlying desire to exonerate Chivington and lay all blame upon Native shoulders. Taking an opposite stance, historians seeking to condemn Chivington and Evans have found plenty of sources that portray them as eager to use violence prior to November 1864, the implication being that they would attack Indians regardless of their hostile or friendly status. One of the most infamous statements attributed to Chivington displays his acutely vengeful attitude toward Indians. S.E. Browne, a Colorado resident and attorney questioned at the congressional hearings on the event, stated that Colonel Chivington had publicly announced in August or September of 1864, that his policy was to "kill and scalp all, little and big; that nits made lice." 22 Authors such as Ralph Andrist, Dee Brown, Thom Hatch, and Duane Schultz all highlight similar evidence to assert theses diametrically opposed to that of Craig. ${ }^{23}$

\section{The Indians at Sand Creek and the Position of the US Government}

Were the Indians at Sand Creek under the protection of the US government? In answering, "No, they were not," William R. Dunn takes obvious direction from his predecessor, J.P. Dunn. ${ }^{24}$ In Massacre of the Mountains, the latter argues that Black Kettle's camp had received no authorized promise of protection from either Governor Evans or Colonel Chivington, who commanded the region's troops. ${ }^{25}$ Dunn asserts that promises made by Wynkoop and possibly by his successor, Anthony, were outside their authority. Reginald Craig sees it differently, asserting that while Black Kettle had sued for peace, he had done so only as a ploy to gain time to regroup and strengthen his people's resistance. ${ }^{26}$ In Bury My Heart at Wounded Knee, Dee Brown sees the situation from yet another perspective, arguing that Black Kettle's camp was under government protection and that not only had Black Kettle sent most of his warriors off to hunt buffalo but the encampment was so confident of "absolute safety, [that] they kept no night watch except of the pony herd which was corralled below the creek." 27 Attempting to corroborate this position, Brown cites the testimony of Edmund Guerrier (the mixed-blood son-in-law of frontiersman William Bent), who was encamped at Sand Creek on the morning of the attack. Of that morning Guerrier remembered the following: "I heard, at first, some squaws outside say there were a lot of buffalo coming into camp." ${ }^{28}$ Brown paints the encampment as completely unaware of the possibility of an attack. By carefully selecting from among the disparate sources, Brown and Craig were able to come to well-documented but opposite conclusions. ${ }^{29}$

\section{Sand Creek: A massacre or a battle?}

Did the events at Sand Creek constitute a massacre or a battle? In his answer to this question, William R. Dunn emphasizes the preparedness of Black Kettle's encampment: they had dug rifle pits and, according to Dunn, were caught by surprise only as a result of Chivington's secretive operations. ${ }^{30}$ Yet Dunn provides no other evidence to support his conclusion that the events at Sand Creek were a battle and not a massacre, and offers no discussion of the conflict itself. Most other participants in the debate have provided more evidence to support their claims. Instead of arguing that the Indians fled from battle, Craig contends that the hand-to-hand combat the Indians engaged in constituted an organized retreat and a simple extension of the battle to predetermined defensive strongholds. ${ }^{31}$ Craig even cites examples of Black Kettle himself engaging in the battle. ${ }^{32}$ 
To emphasize Black Kettle's pacifist desires, others offer accounts describing the Cheyenne chief holding aloft an American flag he received from President Abraham Lincoln in hopes of convincing the approaching troops not to fire. ${ }^{33}$ Not only does this paint a scene of cruel irony and betrayal, it suggests that Black Kettle's band had no desire to fight. Indeed, the very vocabulary that many authors use to describe Sand Creek suggests a very different story from the notion that the Indians were itching for a battle. Peter Matthiessen has described the events of 29 November 1864 as "the slaughter [of] an unsuspecting Cheyenne camp by an armed mob of Colorado irregulars"; Duane Schultz uses such terms as "primate," "unrestrained," "crude," and "barbaric" to describe the mob. ${ }^{34}$ Again, these authors' analyses are based on conflicting sets of primary documents. The primary sources depict Sand Creek as both a battle and a massacre. There are, in fact, scenarios that cite the presence of both many Indian warriors and almost none-and mortality levels follow a similar pattern of disagreement. One account states that "[t]he Indians returned our first fire almost instantaneously," whereas another tells of a defensive group that "just flocked in a promiscuous herd, men, women and children together." 35 Another suggests that women and children were in fact being used as a shield while the warriors organized a counter-offensive. ${ }^{36}$ Testimonies can be found to support either side, and, by using only one side of the testimonial evidence and ignoring the half that contradicts their thesis, authors can conveniently present evidence fitting the story they wish to convey. Whether or not the Cheyennes were prepared for battle or offered serious resistance, however, they were nevertheless slaughtered. For this reason, the term "massacre" has largely been accepted.

\section{Were excessively large numbers of women and children killed at Sand Creek?}

Of all the aspects of the Sand Creek Massacre, the report that large numbers of women and children were killed has proved among the most inflammatory. William R. Dunn attempts to disarm this accusation by quoting Acting Battalion Adjutant Stephen Decatur, who testified that "I counted 450 warriors (dead), and do not think there were any more women and children killed than would have been killed in attacking a village of whites of the same number." ${ }^{37}$ Dunn offers no corroborating evidence. Decatur's testimony is similarly used by Craig to explain that "[s]everal squaws were shot while fighting beside the men, using spears, bows and arrows and muskets with as much dexterity as the warriors; and several children were struck by stray bullets." ${ }^{38}$ Craig therefore concludes,

From all the circumstances, it appears that probably not over one-fourth of the dead were women, most of whom were killed fighting the troops, and that there were few children killed and most of them by accident. ${ }^{39}$

Craig adds the testimony of Robert Bent, who claimed that "noncombatants had every opportunity to escape." 40

Other authors present numerous testimonies to the contrary. Duane Schultz cites accounts of women surrendering and begging for mercy but being shot nonetheless; of a six-year-old girl who was shot while holding a white flag; and of a five-year-old girl's being shot as she tried to hide in the sand. ${ }^{41}$ David Stannard relates Major Scott Anthony's testimony, which tells of a three-year-old child's being shot for sport. ${ }^{42}$ The testimony of one James P. Beckwith is cited by Dee Brown to counter views like Craig's by asserting that the slaughter of women and children not only occurred but was intended. ${ }^{43}$ Beckwith 
testified that Chivington instructed the troops as follows: "I don't tell you to kill all ages and sex, but look back on the plains of the Platte, where your mothers, fathers, brothers, sisters have been slain, and their blood saturating the sands on the Platte." ${ }^{44}$ Chivington's statement implies a possible planned retribution. Further, Beckwith testified that among those killed "[t]here were all sexes, warriors, women, and children, and all ages, from one week old up to eighty years," and that "about two-thirds" of those killed were women and children. ${ }^{45}$ Clearly, there is ample testimony that authors on both sides can use to make opposing claims. However, the claim that no unarmed women or children were killed constitutes little more than denial. The primary documents disagree on many facts, but the killing of numerous unarmed Cheyennes is irrefutable. Although Craig, J.P. Dunn, and William R. Dunn attempt to justify some of these facts and simply deny others, the historical record is clear on the broader issue of these killings, despite some confusion about the details.

\section{Did Chivington permit the scalping and mutilation of the Indian dead?}

William R. Dunn writes, "There were some Indian scalps taken, and probably some mutilation of the Indian dead, but certainly this was done without Colonel Chivington's knowledge or approval." 46 This statement raises two important questions: Were bodies scalped and mutilated? and, if so, Was Colonel Chivington aware of such atrocities? Reginald Craig either denies such mutilations outright, quickly discrediting the sources that describe such events, or justifies them by saying that it was common frontier belief that scalping or mutilation was the only way to truly strike fear into the hearts of Indians. ${ }^{47}$ In addition, he argues that the overwhelming spirit of vengeance felt by Colorado citizens as a result of Indian attacks on settlers explains away their guilt. ${ }^{48}$ In either case, Craig vehemently defends these actions by emphasizing documents that support his thesis and quickly discarding those that do not. Dunn cites the testimony of Irving Howbert (one of the most supportive of the Third Cavalry's actions) as justifying any misdeeds in light of the horrors of the Indian depredations from the previous summer. Although he had not personally seen anyone in the act of scalping Indian bodies, when faced with the fact that it had occurred, Howbert reasoned that

[t]hey had probably been scalped by some of the reckless persons referred to, or possibly by some of the many men in the regiment whose relatives or friends had been killed and brutally mutilated by the savages during the preceding summer. I am not apologizing for the acts of these people, but every fair-minded person must admit that there may have been extenuating circumstances connected with the offense, and no one unfamiliar with the horrors of savage warfare can appreciate the feelings of those who have suffered from their attacks. ${ }^{49}$

In other words, both Howbert and Dunn claimed that if any soldiers actually did scalp or mutilate Indian bodies, their actions were due to the psychological trauma they had suffered themselves. On the numerous first-hand accounts and testimonies that condemned the Third Cavalry's actions, Craig is largely silent. Even though there is ample documentary evidence to oppose his claims, Craig highlights only those that bolster his thesis.

Even those elements of the secondary literature that largely support the views and actions of the Third Cavalry admit that some scalping and mutilation of bodies occurred. Accounts that condemn the Third Cavalry focus largely on such mutilation, ostensibly in order to cast the entire event in such a light. The accounts of Duane Schultz, Thom Hatch, Ralph Andrist, and others all feature excerpts from testimonies that de- 
scribe live captives - as well as those already dead - being scalped and otherwise mutilated. These testimonies describe women being raped and then shot, Indians wandering blindly around the battlefield with their scalps missing, men's and women's genitals being cut off and placed decoratively on the soldiers' horses' bridles or taken to be used as tobacco pouches, women's breasts being cut off and worn as caps, fingers being cut off to facilitate the theft of jewelry, and Indian women killing themselves and their children in order to escape a more brutal death. ${ }^{50}$ Duane Schultz reports that the "orgy of murder and mutilation" was so tiring that many soldiers had to lie down and rest before continuing. ${ }^{51}$

While the testimonies that describe these horrific scenes assert that such depredations did occur, Chivington's involvement is another issue entirely. The evidence cited by both Duane Schultz and Dee Brown to prove that Chivington was aware of such atrocities comes from Lieutenant James Connor, who testified that "according to the best of my knowledge and belief these atrocities that were committed were with the knowledge of J. M. Chivington, and I do not know of his taking any measures to prevent them." 52 Since opposing authors cite either Connor to condemn Chivington or Howbert to exonerate him, it is difficult to draw a firm conclusion as to the "truth" of the matter. As with so many aspects of the Sand Creek Massacre, the historian must decide to which testimonies he or she should give credence. Whichever side these historians' conclusions fall upon, they represent incomplete histories. Though scholars are certainly not obliged to use testimonies that contradict their interpretation, a discussion of why the author has discounted such sources would strengthen his or her conclusions. The biased approach used in these studies devalues them and calls their conclusions into question. The result is a murkiness as to how the Sand Creek Massacre, a potential topic of insightful study, fits into the wider backdrop of genocide in the world.

\section{Citing Sand Creek:The Historiographic Casualty}

Because the Sand Creek Massacre is a prominent event in the history of the North American West, its unbalanced portrayal in the historiography is deleterious in several ways. Most immediately, it perpetuates the problem of unbalanced research and polemical conclusions. Relying on Ward Churchill's emphasis on Chivington's supposed bloodlust and its gruesome outcome, ${ }^{53}$ for example, M. Annette Jaimes has drawn a conclusion that epitomizes the troublesome end result of biased research. First, based on Churchill's statement that all of the Colorado Third Cavalry, like the Nazi SS, was a "criminal organization, formed solely for criminal purposes and composed of criminal individuals," Jaimes concludes that the Sand Creek Massacre and other like events typify American West history. ${ }^{54}$ In other words, instead of viewing such events as anomalies in America's westward expansion, she sees them as representative of the region's history. Jaimes's and Churchill's claim that Sand Creek is the "normative expression" of American civilization is striking. While this view represents an extreme interpretation of the historiographic record, it highlights a significant concern: a historiography dominated by biased literature can lead to extreme conclusions.

Such broad generalizations about all of the American West, or all of American history, constitute a fatal flaw. There is no argument that the Sand Creek Massacre, the Wounded Knee Massacre, the Sappa Creek Fight, the Bear Creek Massacre, and the Washita River Massacre were pivotal in the history of the West, but to suggest that they represent America as a whole is not a little troublesome. If the events at Sand Creek did indeed represent 
the desires of all Americans and constitute government policy, then why were they followed by widespread public outcry? The extensive military and congressional inquiries into the event, not insignificant occurrences, also imply a lack of government approval.

In their effort to explicitly tell the Native American side of American history, studies such as Jaimes's exemplify a general reaction to past scholarship that primarily portrayed the Euro-American perspective on the history of the American West. There is no doubt that this earlier Eurocentric emphasis was in dire need of revision; but some scholars have swung the pendulum so far that they now present history from a different but equally biased and ethnocentric perspective.

In his review of David Stannard's American Holocaust, Samuel R. Cook of the University of Arizona claims that it is "necessary to counterbalance the ethnocentricities of past historical works on Natives." ${ }^{55}$ However, the claim that works such as Stannard's accomplish this goal stands on a precarious and ultimately hypocritical foundation. To attempt to right the wrongs of past ethnocentric scholarship by writing new ethnocentric scholarship is academically irresponsible. The cliché that two wrongs do not make a right has never rung clearer. Clear evidence of this is the work of William R. Dunn, which explicitly sought to swing the pendulum of historical interpretation in the opposite direction; a struggle has now emerged in which competing "sides" with competing perspectives attempt to "balance" the historiographical record by using non-objective methodologies and drawing biased conclusions. Incessant vilification or single-minded defense of either Euro-Americans or Native Americans by some historians is counterproductive and interferes with efforts to establish a solid historical record of the history of the American West, particularly with respect to whether and what type of genocidal activity may have taken place. To suggest that events like the Sand Creek Massacre were typical of IndianAmerican relations, or to stubbornly justify such events without admitting any American wrongdoing, is to place oneself largely outside the realm of objective scholarship.

The Sand Creek Massacre can provide important information for those conducting research into the origins of genocidal actions. For example, while the ill-treated subject of intercultural miscommunication and confusion does not explain away the obvious elements of rancor and revenge exhibited by Evans and others, it could at least foster a more complex explanation for events surrounding Sand Creek than the monocausal reasoning requisite for simply assigning guilt. Understanding what caused such confusion, acrimony, and friction among these groups, and how these problems led to a series of violent events, including the Sand Creek Massacre, would be a more productive avenue of research. While there are numerous examples of contemporaneous violent outbreaks, none of these devolved into such wholesale butchery - in quantity or in quality. The historian's task, therefore, involves determining whether Sand Creek was a tragic massacre or a justified battle, as well as attempting to discover how and why the events of 29 November 1864 unfolded differently from other contemporaneous events and resulted in such catastrophe. The polemics and politics engaged in by many of the authors whose work is explored above have resulted in many weighty and significant questions' being left underexplored. With few exceptions, the resulting historiography is a confusing, confrontational body of scholarship that makes comparative genocide research just that much more difficult.

More careful analysis of the Sand Creek Massacre could certainly prove useful to genocide scholars. Though not without its faults, one of the stronger works currently available is Stan Hoig's The Sand Creek Massacre, published in 1961. Unlike the other 
studies discussed here, Hoig's interpretation is supported by a fair selection of documents from both sides of the historical record. The Sand Creek Massacre should not be placed on a pedestal or touted as a paragon of objective research, but Hoig's study does exhibit a much greater degree of objectivity than most others do. Hoig's contextualization of the Sand Creek Massacre shows the faults and merits of both Native Americans and whites. In his initial six chapters, Hoig relates the series of bloody conflicts and the resulting escalation of tensions that led to the massacre on 29 November 1864. To accomplish this task, Hoig selected a wide range of documents-including newspapers, personal correspondence, government reports, and secondary analyses - that reflect both sides of the conflict. For example, in laying out the situation of Indian affairs in 1863, Hoig has been careful to detail Cheyenne, Ute, Comanche, Kiowa, Sioux, Caddoe, and Arapaho offensives along with attempts by various United States military units to suppress these attacks. In addition to describing the events themselves, his documentation delineates the motives and reasoning behind each group's actions. In his analysis Hoig shows that some conflicts were initiated by Indians and others by whites. ${ }^{56}$ In stark contrast to other accounts that display an eagerness to assign sole blame to one side or the other, Hoig's more careful analysis does not excuse either side for their aggression and assigns guilt and innocence much more judiciously.

This more careful analysis continues as Hoig follows the history through to the Sand Creek Massacre. Whereas other texts show a bias in the author's choice of sources, Hoig consulted a fair selection of testimonies from both sides of the debate. He cites the testimonies of Irving Howbert, John Smith, Colonel John Chivington, James P. Beckwith, Major Scott Anthony, Major Hal Sayr, Major Edward Wynkoop, and many others. For example, in describing the death of the prisoner Jack Smith, Hoig is careful to offer both testimonies that describe the death as an accident and others claiming that it was murder. ${ }^{57}$ Though Hoig comes down on the side of murder, he first offers evidence supporting the counterargument. Again, unlike the other accounts described above, The Sand Creek Massacre includes an analysis of a wide range of sources, more thoroughly presents the different perspectives of the different sides in the conflict, and attempts to provide a more holistic context for the event. The resulting text is much more valuable for comparative research than the other works discussed thus far.

\section{The Challenge of Integrating the History of the North American West into the Field of Genocide Studies}

Ultimately, regardless of whether the depopulation of America's autochthonous peoples is officially defined as genocide, mass murder, casualties of war, or simply the unfortunate consequence of post-Columbian contact, careful study of such events can be of great benefit. The fact remains that, for millions of Native Americans, European contact brought violent conflict and violent death, and the cataclysmic events that followed merit careful study. The value of understanding this history lies not only in enabling Native American groups to understand their regional, cultural, or ethnic history but in helping the world to understand its own.

Unfortunately, events and incidents of the North American West have too seldom been examined in the context of comparative genocide studies. Efforts to expand the study of such events are needed, but they must be as objective as possible, for only then will the insights and new knowledge gleaned be of value. 
It is also true, however, that the political foundation from which many authors draw is a major obstacle to the development of more objective research in the field and to subsequent integration with the field of genocide studies. The political roots of many in the field of Native American studies help explain the apparent dearth of objective comparative scholarship. The temptation for some has been to deny any academic or historical value to activist literature; such a stance, however, fails to appreciate the important social trends that such literature represents. To dismiss such scholarship as nothing more than political rhetoric is to deny contemporary Native Americans a voice in their own history. Furthermore, this dismissive attitude fails to recognize that the legacies of North American history have brutally real effects on the day-to-day life of indigenous people, effects that extend far beyond the realm of mere political posturing. As in any other field, each study must be assessed on its own merits.

In the late 1960s, amidst myriad other social and civil-rights movements, the American public witnessed one of the first manifestations of a large-scale Native American activist movement. Through the years this movement took on many shapes and foci. ${ }^{58}$ Some of the primary struggles dealt with issues of political autonomy, religious freedom, control over self-image, and traditional Indian land rights. The historical literature that emerged represented an attempt by Native American scholars to revise what they viewed as onesided, biased, Eurocentric histories of their past. Their historical analyses were aimed not only at re-establishing control over their own past but also at justifying contemporary political, social, economic, or religious reform. It should be no surprise that much of their work took on a political and impassioned tone.

Perhaps the most influential of the early Native American activist writers was Vine Deloria, Jr. Deloria was born a Standing Rock Sioux; in 1969, his first major publication, Custer Died for Your Sins, sent shockwaves through both Native and non-Native communities and established an ideological framework of topics and themes that can be traced throughout the subsequent years of the movement. ${ }^{59}$ As some of the titles and subtitles of his books suggest (We Talk You Listen; An Indian Manifesto; An Indian Declaration of Independence), Deloria's writings strongly voiced Native frustration and issued a vigorous call for reform. ${ }^{60}$ Deloria's prolific writing covered such foundational topics as treaty making, the ins and outs of political sovereignty, and self-government, and broadened out to encompass issues of religious freedom, community solidarity, social autonomy, and cultural self-determination. ${ }^{61}$

Throughout his writings, Deloria's response to previous scholarship on the Native American experience is clear: Native Americans must stop looking outward and start looking inward for their sense of identity, political autonomy, and spiritual understanding. Ultimately, this response came to encompass the whole of the Indian activist movement: a reaction against a long history of Native Americans' being forced (though in some cases they did so of their own volition) to look outside of themselves and their communities for their well-being. While Deloria played a valuable role in articulating the justifiable frustrations and grievances that Native Americans felt about their past and present conditions, uniformly applying his reactionary and politically based methodology and perspective to objective comparative genocide scholarship presents problems.

The mass of Deloria's work - and that of many who have followed him-focused on analyzing historical events for the purpose of advocating contemporary political and cultural change. This is the same goal that some have proposed for studying possible genocide in general. While the dividing line between scholar and activist is one that proves 
difficult to clarify, some individuals from both groups use the study of the past to bring about change in the present world. However, genocide studies' goal - to better understand genocide as a phenomenon in order to prevent its future reoccurrence - is fundamentally different from Deloria's goal of using historical analysis to demonstrate ongoing injustices toward Native Americans and to justify changing fundamental tribal relationships with the US government. When authors admit that their historical research is fueled by "unequivocally political" motives and declare no more than an "abstract allegiance" to academic issues, as Ward Churchill does in his 1997 A Little Matter of Genocide, there is cause for concern. ${ }^{62}$ While Churchill's admittedly polemic treatise may represent the extreme, the phenomenon of politically fueled research is widespread. One manifestation of this phenomenon is the high number of indigenous authors who list their tribal affiliation in their publications, seemingly in an attempt to add political and cultural weight to their views. ${ }^{63}$ There is no fundamental problem with writing from a political standpoint, but such biases must be acknowledged and analyzed in order to determine a study's overall usefulness, particularly if it is to be used in the realm of comparative genocide studies.

In his review of Marc Bloch's theorizing on comparative studies, William Sewell explains that comparative methodology, by design, should reduce our personal biases by forcing us to confront alternative views. ${ }^{64}$ The underlying assumption is that our comparative analysis is objective enough to consider alternate views. If authors are unwilling to devote fair attention to opposing views and explanations of historical events, then what use is there in searching for greater historical insight by attempting to compare events in the first place? This does not imply, for example, that Holocaust historians must devote significant time to the issue of Holocaust denial; however, it does suggest that, in analyzing historical events, they should discuss a wide spectrum of primary source evidenceincluding alternative views that may run counter to their arguments (a classic case being the functionalist versus intentionalist argument of years past). If nothing else, such open and frank discussion will strengthen their arguments; readers are less likely to feel as though the proverbial wool is being pulled over their eyes, and all interested parties will gain a more informed understanding of the subject.

In the study of possible genocidal events, historical characters are bound to be labeled as victims and perpetrators. In the case of the Holocaust, it is fairly clear who committed murder and who the victims were; but the history of white-Indian violence is more complex. Not only does the history of their interactions span centuries, involve innumerable disparate groups and individuals, and cover widely different geographical zones, it is also a fact that atrocities were committed by both sides. Highly selective and unbalanced presentation of primary documents cannot hope to produce a solid understanding of why and how such atrocities were perpetrated. Indeed, ultimately, it may prove impossible to discern how and why contentious cross-cultural interactions escalated into genocide if scholars are more focused on condemning or exonerating the parties involved than on conducting a sophisticated analysis of the facts.

The negative impact of overt bias on history is well described by anthropologist Bruce Trigger: "such biases may simply add harmless colour to a dry story, but they can [also] turn historical study into a dangerous piece of propaganda." ${ }^{65}$ Robert Athearn similarly complains, in his review of Ralph Andrist's The Long Death, "It is all right for an author to have a point of view, but in this case it is waved in the reader's face at every turn." 66 To some degree, Athearn is correct. ${ }^{67}$ With his usual candor, Ward Churchill mused that his 
study A Little Matter of Genocide would not be well received in the academic community because it contains similar extreme posturing. ${ }^{68}$ In his review, sociologist Kurt Jonassohn absolves Churchill of such misdeeds: "The reader should not be distracted by errors and interpretations that seem to weaken the overall argument, an argument that is far too important to be dismissed on such grounds." 69 Nevertheless, the work is too obviously biased to be taken at face value.

As heirs to either the Native American or Euro-American legacy of such events, authors are likely to find their personal feelings for or attachment to the subject difficult to escape. Conducting objective research is difficult as it is, and such difficulties are only exacerbated by cultural ties to historical characters and events. These considerations have led James Axtell to theorize further on the role of historians in retelling the past:

The serious historian may not wrap himself in judicial robes and pass sentence on high; he is too involved in both the prosecution and the defense ... the [historian's] goal is not to punish or rehabilitate historical malefactors - who are morally incorrigible - but to set the record straight for future appeals to precedent. ${ }^{70}$

Emphasis should be duly placed on Axtell's use of the term "serious historian." As the historiography shows, it does not take an incredible amount of skill to scrutinize the historical record and point fingers; however, to research and present a balanced portrayal of past events that is useful for comparative research or produces insights to inform future government policy is much more difficult. With respect to the focus of this article, then, it takes the most serious and objective historian to make any balanced sense of the complex and violent interactions between Native American and Euro-American groups.

Another troublesome characteristic of scholarship in this field is a tendency to speak in broad generalizations and oversimplified dichotomies, damaging historical understanding of both the individual and the group in their complex interactions with one another. On the group level, complex historical processes and events cannot be broken down into simple binaries (e.g., "whites versus Indians"). Patricia Limerick argues that

Only in rare circumstances were the affairs we call "white-Indian wars" only matters of whites against Indians. More often, Indians took part on both sides, tribe against tribe or faction against faction, and whites sometimes played surprisingly peripheral roles in the working out of relationships between and among Indian groups. ${ }^{71}$

Yet some scholars insist on framing historical conflicts in such simple terms. For example, to provide a historical background for his arguments on contemporary affairs, Robert Burnette offers a brief survey of 400 years of Euro-Indian relations. In doing so, he suggests that all early Europeans were personified by the Puritan leader Cotton Mather, labeling them "bloodthirsty missionaries," while Native Americans are grouped together and referred to collectively as "The Indian." ${ }^{72}$ Broad generalizations erase the historical intricacies of individual and group interactions, dismissing the complexity not only of relations between various groups of Native Americans and Europeans but also of relations between individuals. ${ }^{73}$

\section{Conclusions}

As peoples across the world struggle to understand and cope with tragedies in their own histories, many look to similar cases from other time periods or other parts of the world. Scholars, of course, do the same thing. By conducting comparative studies, schol- 
ars seek to further and deepen understanding of key events in history. This is certainly true of those genocide scholars who engage in the comparative study of genocide.

In surveys of modern history, the depopulation of America's autochthonous peoples offers an unparalleled variety of comparative examples. The diversity of situations, events, and actors allows for valuable comparisons and contrasts.

If the historiography of one of the North American West's most prominent examples of possible genocide, the Sand Creek Massacre, is any indication of the state of the field, it is obvious that in-depth and solid study of a host of single events is critically needed; only with the benefit of such detailed studies will scholars be able to carry out solid comparative studies. Beyond the Sand Creek Massacre, the history of the North American West and the conflicts between the various empires, cultures, and peoples offer a wealth of material for comparative research. Though such research is not a simple task by any means, the possible results are well worth consideration and further discussion.

\section{Notes}

1. Reginald S. Craig, The Fighting Parson: The Biography of Colonel John M. Chivington (Los Angeles: Westernlore Press, 1959), 46.

2. Ibid., 66.

3. Ibid., 163.

4. Stan Hoig, The Sand Creek Massacre (Norman: University of Oklahoma Press, 1961), $20 \mathrm{n}$.

5. Ibid., 69.

6. Ibid., 82-83n.

7. Though sympathetic to Black Kettle in this case, Wynkoop had previously been actively engaged in destroying the Indians still at war. After the violent summer of 1864, however, Wynkoop seems to have been more ready to accept peaceful terms; see ibid., 90.

8. US Senate, The Chivington Massacre, 39th Cong., 2d sess., 1867, S. Rep. 156, 71.

9. Ward Churchill, A Little Matter of Genocide: Holocaust and Denial in the Americas, 1492 to the Present (San Francisco: City Lights Books, 1997); M. Annette Jaimes, ed., The State of Native America: Genocide, Colonization and Resistance (Boston: South End Press, 1992); M. Annette Jaimes, "Introduction: Sand Creek, the Morning After," in The State of Native America: Genocide, Colonization and Resistance, ed. M. Annette Jaimes, 1-12 (Boston: South End Press, 1992); David Stannard, "Uniqueness as Denial: The Politics of Genocide Scholarship," in Is the Holocaust Unique?: Perspectives on Comparative Genocide, ed. Alan S. Rosenbaum, 163-208 (Boulder, CO: Westview Press, 1996); David Stannard, American Holocaust: The Conquest of the New World (New York: Oxford University Press, 1992).

10. See Steven T. Katz, The Holocaust in Historical Context, vol. 1: The Holocaust and Mass Death before the Modern Age (New York: Oxford University Press, 1994), 91. The study of Native American demography is itself a fiercely debated field, and estimates of how many died after European contact relies largely on estimates of the pre-contact population. While such estimates have ranged from 900,000 to 18 million, few scholars in the field deny that European contact brought about a cataclysmic demographic collapse. See Henry Dobyns, Their Numbers Become Thinned: Native American Population Dynamics in Eastern North America (Knoxville: University of Tennessee Press, 1983); Russell Thornton, American Indian Holocaust and Survival: A Population History since 1492 (Norman: University of Oklahoma Press, 1987), 25-26; Kirkpatrick Sale, The Conquest of Paradise: Christopher Columbus and the Columbian Legacy (New York: Alfred A. Knopf, 1990), 315. Even Stephen Katz, an advocate for the uniqueness of the Holocaust, admits, "Contrasted solely on statistical grounds, the collapse of the Native American population, both absolutely and proportionally, surpasses the destruction of European Jewry." Katz, Holocaust and Mass Death, 119.

11. Patricia Nelson Limerick, Something in the Soil: Legacies and Reckonings in the New West (New York: W. W. Norton, 2000), 61. 
12. Israel Charny, How Can We Commit the Unthinkable? Genocide: The Human Cancer (Boulder, CO: Westview Press, 1982), 5. Jack Porter suggests an extensive array of sociological lessons that may be learned from the study of genocide, including "the process of war and colonialism, the experience of death and extreme deprivation, the meaning of survival and resistance and the very nature of society itself" as tangential subjects that may profit from the study of genocide. Jack Nusan Porter, "Introduction: What Is Genocide? Notes Toward a Definition," in Genocide and Human Rights: A Global Anthology, ed. Jack Nusan Porter, 2-33 (Washington, DC: University Press of America, 1982), 4.

13. For a collection of primary documents, including the reports submitted by the secretary of war and the US Senate concerning the massacre, see John M. Carroll, ed., The Sand Creek Massacre: A Documented History (New York: Sol Lewis, 1973). Most of the congressional documents cited in this survey can be found in this volume, but they are cited here separately as legislative documents.

14. It should be pointed out that the very use of the term "massacre" to describe the event represents some prejudgment of the event. Some authors refer to it instead as a "battle" or "fight." My use of the term "massacre" in this study reflects modern historiography, the majority of which refers to the event as the "Sand Creek Massacre" or "Chivington Massacre."

15. Hoig, Sand Creek Massacre, vii. Even this statement shows some bias on the subject. Hoig's decision to term the event a "conflict" could be questioned, because it implies some degree of Cheyenne resistance - an idea some authors contest: see, e.g., Ralph K. Andrist, The Long Death: The Last Days of the Plains Indians (New York: Macmillan, 1964), 87; Dee Brown, Bury My Heart at Wounded Knee (New York: Holt, Rinehart, \& Winston, 1970), 87.

16. William R. Dunn, I Stand By Sand Creek: A Defense of John M. Chivington and the Third Colorado Cavalry (Fort Collins, CO: The Old Army Press, 1985), viii.

17. Ibid., viii; J.P. Dunn, Massacres of the Mountains: A History of the Indian Wars of the Far West (New York: Harper \& Bros., 1886), 408-15; Craig, The Fighting Parson, 145-65.

18. Mari Sandoz, Cheyenne Autumn (Lincoln: University of Nebraska Press, 1953), 4; Craig, The Fighting Parson, 168-69.

19. See Duane P. Schultz, Month of the Freezing Moon: The Sand Creek Massacre, November 1864 (New York: St. Martin's Press, 1990), 76. J.P. Dunn disagrees, stating that the Dog Soldiers were an integrated part of tribal government, which made Black Kettle responsible for their actions. Dunn, Massacres of the Mountains, 431.

20. Craig, The Fighting Parson, 178.

21. Ibid., 155-56.

22. US Senate, The Chivington Massacre, 71.

23. Andrist, The Long Death, 79; Brown, Bury My Heart, 86; Thom Hatch, Black Kettle: The Cheyenne Chief Who Sought Peace But Found War (Hoboken, NJ: John Wiley, 2004), 147; Schultz, Month of the Freezing Moon, 85-96.

24. Dunn, I Stand By Sand Creek, 144.

25. Dunn, Massacres of the Mountains, 420.

26. Craig, The Fighting Parson, 168-69.

27. Brown, Bury My Heart, 87.

28. Ibid., 87-88. For Guerrier's testimony see US Senate, The Chivington Massacre, 65-66.

29. J.P. Dunn and Ralph Andrist arrive at similarly opposing conclusions on the issue of whether Black Kettle was even aware of possible danger. Dunn, Massacres of the Mountains, 421; Andrist, The Long Death, 87. Thom Hatch and others point to Major Wynkoop's testimony as the strongest proof that Black Kettle's camp was under express government protection. See US Senate, Sand Creek Massacre: Report of the Secretary of War, 39th Cong., 2d sess., 1867, S. Doc. 26, 102-3; and Hatch, Black Kettle, 142.

30. Dunn, I Stand By Sand Creek, 146. The testimonies of Lieutenant Joseph Cramer and Corporal Amos Miksch indicate otherwise. Having surveyed the battleground after the event, Cramer stated that there were no rifle pits. See US Senate, The Chivington Massacre, 74. Amos Miksch recalled that "there 
were no rifle-pits except what the Indians dug into the sand bank after we commenced firing. I saw them digging out sand with their hands while firing was going on; the water came into the trenches they dug in this manner." Ibid., 75.

31. Craig, The Fighting Parson, 194.

32. Ibid.

33. Andrist, The Long Death, 89; Hatch, Black Kettle, 147; Schultz, Month of the Freezing Moon, 134. William R. Dunn flat-out denies that any flags were flown by Black Kettle; though he provides one source as evidence, he ignores the numerous sources that attest the opposite. Dunn, I Stand By Sand Creek, 145.

34. Peter Matthiessen, In the Spirit of Crazy Horse (New York: Penguin, 1980), 6 (emphasis added); Schultz, Month of the Freezing Moon, 134-35, 137.

35. US Senate, The Chivington Massacre, 67, 41.

36. Ibid., 41 .

37. Dunn, I Stand By Sand Creek, 146.

38. Craig, The Fighting Parson, 194.

39. Ibid., 195.

40. Ibid.

41. Schultz, Month of the Freezing Moon, 138. For Robert Bent's complete testimony see US Senate, The Chivington Massacre, 95-96.

42. Stannard, American Holocaust, xi. Major Anthony recalled the following:

There was one little child, probably three years old ... I saw one man get off his horse, at a distance of about seventy-five yards, and draw up his rifle and fire-he missed the child. Another man came up and said, "Let me try the son of a bitch; I can hit him." He got down off his horse, kneeled down and fired at the little child, but he missed him. A third man came up and made a similar remark, and fired, and the little fellow dropped.

US House, Massacre of the Cheyenne Indians: Report on the Conduct of War, 38th Cong., 2d sess., 1865, H. Rep. 142, 27.

43. James P. Beckwith is also known in many sources as "James P. Beckwourth." Because the records cited here refer to him as "Beckwith," that spelling is used in the text.

44. US Senate, Sand Creek Massacre, 68.

45. Ibid., 70-71. Beckwith also reported that Jack, son of Bent, St. Vrain \& Company Indian trader John S. Smith, was shot from behind while exiting a lodge, long after the battle was over.

46. Dunn, I Stand By Sand Creek, 146.

47. J.P. Dunn makes the following observations on this concept: "Scalping and mutilation also strike terror to the Indian heart. Their religious belief is that the spirit in the next world has the same injuries that were inflicted on the body here . . . That the Sand Creek affair inspired them with terror is beyond question." Dunn, Massacres of the Mountains, 426-27.

48. Craig, The Fighting Parson, 216-17. Craig closely follows the reasoning of J.P. Dunn, who writes, "There is a certain amount of justice in the theory of meting to a man in his own measure, and the people of Colorado had old scores to pay in the accounts of murder, robbery, and rape." Dunn, Massacres of the Mountains, 427. Dunn continues by detailing some depredations committed by Plains Indians, and concludes as follows:

The people of Colorado did want revenge, and these men, who had been cooped up all summer in towns and blockhouses, whose crops were ruined, whose stock had been run off, whose houses had been burned, who had been eating bread made of fortyfive-dollar flour, who had buried the mutilated bodies of their neighbors, in helpless wrath, who had heard stories of the women captives - these men marched to Sand Creek, with the fire of vengeance in their hearts, and quenched it in blood. 
According to Dunn, this explains why Indian bodies were mutilated at Sand Creek and, judging by the tone of his reasoning, somewhat exculpates the guilty parties. Dunn, Massacres of the Mountains, 429-30.

49. Irving Howbert, The Indians of the Pike's Peak Region (1914; reprint, Glorieta, NM: Rio Grande Press, 1970), 178; Dunn, I Stand By Sand Creek, 146-47.

50. Churchill, A Little Matter of Genocide, 233; Hatch, Black Kettle, 159-66; Schultz, Month of the Freezing Moon, 138-39.

51. Schultz, ibid., 139.

52. See Brown, Bury My Heart, 90; Schultz, Month of the Freezing Moon, 139. For Connor's testimony see US Senate, The Chivington Massacre, 53. Major Anthony also reported that the single instance of mutilation that he observed took place while Colonel Chivington was standing by his side. See US House, Massacre of the Cheyenne Indians, 27.

53. Churchill, A Little Matter of Genocide, 228-34.

54. Jaimes, The State of Native America, 3, 5 .

55. Samuel R. Cook, review of American Holocaust: Columbus and the Conquest of the New World by David E. Stannard, American Indian Quarterly 19 (1996): 241.

56. Hoig, Sand Creek Massacre, 23, 41, 51.

57. Ibid., 155-58.

58. Such terms as "Native American activist movement" or "Native American activism" refer to these phenomena in the broadest and most general sense, and not to specific groups or people, unless otherwise noted.

59. Vine Deloria, Jr., Custer Died for Your Sins: An Indian Manifesto (London: Macmillan, 1969).

60. Vine Deloria, Jr., We Talk You Listen (New York: Macmillan, 1970); Deloria, Custer Died for You Sins; Vine Deloria, Jr., Behind the Trail of Broken Treaties: An Indian Declaration of Independence (New York: Delacorte Press, 1974).

61. In 1881, Helen Hunt Jackson penned a scathing exposé of US Indian policy titled A Century of Dishonor. Jackson's documentation of deceit, dishonesty, and murder ran counter to mainstream scholarship and appealed to the American people to demand that Congress act to right past wrongs. Helen Hunt Jackson, A Century of Dishonor: A Sketch of the United States Government's Dealings with Some of the Indian Tribes (New York: Harper \& Bros., 1881; reprint, Minneapolis: Ross \& Haines, 1964), 30. For the next eighty years, however, few followed Jackson's lead. Finally, in 1964, Ralph Andrist published The Long Death, a treatise on Native loss that "might well have been dedicated to Helen Hunt Jackson," according to one reviewer: Robert G. Athearn, review of The Long Death: The Last Days of the Plains Indians by Ralph Andrist, Journal of American History 52 (1965): 379-80; Ralph K. Andrist, The Long Death: The Last Days of the Plains Indians (New York: Collier, 1964). From Jackson Deloria inherited a tradition of using historical analysis as justification for contemporary reform, and from Andrist a poignant writing style that relies upon an emotive vocabulary and imagery.

62. Churchill, A Little Matter of Genocide, 11.

63. It is not my intention to discredit authors who state their tribal affiliations, because there is nothing inherently wrong with doing so. If nothing else, it notifies the reader of the author's indigenous perspective. But it also alerts the reader to possible cultural, religious, or otherwise personal ties the author has to the subject. For a few examples see Eva Marie Garroutte, Real Indians: Identity and the Survival of Native America (Berkeley: University of California Press, 2003); Jaimes, The State of Native America; Fremont J. Lyden and Lyman H. Legters, eds., Native Americans and Public (Pittsburgh: University of Pittsburgh Press, 1992); MariJo Moore, ed., Genocide of the Mind: New Native American Writing (New York: Thunder's Mouth Press, 2003); John Yewell, Chris Dodge, and Jan DeSirey, eds., Confronting Columbus (London: McFarland \& Co., 1992). Ironically, it is here that Ward Churchill himself has attracted considerable trouble: some Native groups, including the American Indian Movement, have largely disavowed Churchill and challenged his claims of being Native American at all. See American Indian Movement, "Is This One and the Same Person? You Decide," 
http://aimovement.org/mckiernan.html (accessed January 6, 2009).

64. William H. Sewell, Jr., "Marc Bloch and the Logic of Comparative History," History and Theory 6 (1967): 208-18, 218.

65. Quoted in James Axtell, After Columbus: Essays in Ethnohistory of Colonial North America (New York: Oxford University Press, 1988), 18.

66. Athearn, review of The Long Death, 380.

67. From the book's inflammatory title, The Long Death, to his choice of chapter titles (including "Massacre in Minnesota," “Nits Make Lice," and "Ten Million Dead Buffalo”), Andrist makes no excuse for his perspective.

68. Churchill, A Little Matter of Genocide, 11.

69. Kurt Jonassohn, review of A Little Matter of Genocide: Holocaust and Denial in the Americas, 1492 to the Present, by Ward Churchill, American Historical Review 104 (1999): 867-68. While Churchill's study synthesizes an impressive amount of information, covers a wide variety of topics, and boasts extensive footnotes and bibliographic information, the overtly biased tone in which it is written is distracting.

70. Axtell, After Columbus, 20.

71. Limerick, Something in the Soil, 33-34.

72. Robert Burnette, The Tortured Americans (Englewood Cliffs, NJ: Prentice Hall, 1971), 12. Burnette's use of Cotton Mather (one of the most extreme examples of inflammatory rhetoric he could have chosen) to represent the whole of the Pilgrim community is troublesome; moreover, the further division of the entire American population into two simple groups - Indians and white men - is a gross oversimplification.

73. Patricia Limerick offers further insight into the problems of too readily grouping individuals into large generalized groups and categorizing those groups along simplified lines. As she observes,

When Anglo-Americans look ... into an Indian reservation, they are more likely to see stereotypes than recognizable individuals or particular groups; the same distortions of vision no doubt works the other way too. The unitary character known as "the white man" has never existed, nor has "the Indian." Yet the phrases receive constant use, as if they carried necessary meaning.

All historians of white-Indian interaction and conflict, regardless of how they interpret the past, would do well to strike these unitary platitudes from their lexicons. The stereotypes, caricatures, and generalizations that plagued the contemporary thought of decades past should not find footing in the lexicon of modern historical analysis. Studies that speak in such simple terms of "the Indian" and "the white man" are bound by their own limited scope to misrepresent historical events and figures. Patricia Nelson Limerick, The Legacy of Conquest: The Unbroken Past of the American West (New York: W.W. Norton, 1987), 349.

Brenden W. Rensink is a Ph.D. candidate in the Department of History at the University of Nebraska-Lincoln, focusing on the field of Native American genocide studies and its relation to the broader fields of genocide studies and the Holocaust. He is the author, most recently, of "Nebraska and Kansas Territories in American Legal Culture: Territorial Statutory Context" in The Nebraska-Kansas Act of 1854, edited by John R. Wunder and Joann M. Ross (University of Nebraska Press, 2008). 